\title{
Development and polymorphism of simple sequence repeat DNA markers for Shorea curtisii and other Dipterocarpaceae species
}

\author{
TOKUKO UJ INO, TAKAYUKI KAWAHARA $\uparrow$, YOSHIHIKO TSUMURA*, \\ TERUYOSHI NAGAMITSU, HIROSHI YOSHIMARU \& WICKNESWARI RATNAM $\$ \S$ \\ Bio-technology Division, Forestry and Forest Products Research Institute, Kukizak, Ibaraki, 305-865-7 J apan, \\ $\uparrow$ Present address, Hokkaido Research Centre, Forestry and Forest Products Research Institute, Hitsujigaoka, \\ Toyohira-ku, Sapporo, 062-0045 J apan, łForest Research Institute Malaysia, Kepong, 52109 Kuala Lumpur, \\ Malaysia, §Present address, Faculty of Life Sciences, University Kebangsaan Malaysia, 43600 UKM Bangi, Selangor \\ Darul Ehsan, Malaysia
}

\begin{abstract}
Nine simple sequence repeat (SSR) markers were developed from Shorea curtisii using two different methods. One SSR locus was isolated by the commonly used method of screening by colony hybridization, and the other eight loci were isolated by a vectorette PCR method. Primer pairs were designed based on the sequences of all these SSR loci. Analysis of 40 individuals of $S$. curtisii from natural forest in Malaysia revealed that all SSR loci were polymorphic. Four SSR markers, Shc01, Shc04, Shc07 and Shc09, were highly polymorphic. We have also tested the applicability of these SSR printers to other species of Dipterocarpaceae using PCR amplification. Because the flanking region sequences of the $S$. curtisii SSRs were well conserved within this family, the SSR primers for S. curtisii can be applied to almost all species of Dipterocarpaceae.
\end{abstract}

Keywords: Dipterocarpaceae, microsatellites, polymorphism, SSRs, tropical forest.

\section{Introduction}

Simple sequence repeats (SSRs), or microsatellites, consist of tandem repeats of 1-4 nucleotide motifs which are distributed throughout eukaryotic genomes (Charlesworth et al., 1994). SSR loci would be expected to show high levels of length polymorphism, on account of differences in the number of repeat units, and to show codominance. In addition, once specific primers have been designed, SSR loci can be amplified from small amounts of genomic DNA by PCR. Therefore SSR markers are useful and powerful tools for population studies. Recently, SSR markers have been developed for several woody plants (Smith \& Devey, 1994; Dow et al., 1995; Kostia et al., 1995; Echt et al., 1996; Van de Ven \& McNicol 1996; Chase et al., 1996a).

Shorea curtisii is a species of the Dipterocarpaceae, a family that includes major component species of the tropical forests of south-east Asia. Although the family is important in tropical forestry and ecosystems, genetic information about member species is limited. Therefore, to determine genetic

*Correspondence. E-mail: ytsumu@ffpri.affrc.go.jp diversity and structure in $S$. curtisii and related species, we planned to develop a series of SSR markers.

Several improvements in methodology have been reported recently for efficient developments of SSR markers (Ostrander et al., 1992; Karagyozov et al., 1993; Lyall et al., 1993; Cifarelli et al., 1995; Kirkpatrick et al., 1995; Takahashi et al., 1996), one of which is the vectorette PCR strategy (Lench et al., 1996). The procedure relies on PCR amplification using a vectorette-specific primer in combination with anchored dinucleotide repeat primers.

In this study, SSR markers of $S$. curtisii were developed using a vectorette PCR method and a general method involving screening by colony hybridization. The applicability of these primers to other species of the Dipterocarpaceae was also examined.

\section{Materials and methods}

Plant materials

Leaves of $S$. curtisii were collected at the research plot at Semangkok Forest Reserve in Serangor, 
Malaysia (Niiyama et al., 1993). The leaves of various other species of Dipterocarpaceae were collected from the arboretum of the Forest Research Institute of Malaysia (FRIM). Total DNA was extracted from leaves of each individual by a slightly modified CTAB method (Tsumura et al., 1996).

\section{Screening the genomic DNA library}

The genomic DNA samples were digested with Sau3AI, HaeIII, AluI and RsaI, and fragments of 300 to $500 \mathrm{bp}$ were fractionated. The DNA fragments were ligated into pUC18, and the ligation mixtures were then transformed into E. coli JM109. Colony hybridization was carried out using a DIG detection kit (Boehringer Co. Ltd) according to the manufacturer's instructions, except that $6 \times$ SSC was used in the hybridization buffer. Two oligonucleotides, $(\mathrm{CA})_{15}$ and $(\mathrm{CT})_{15}$, were used as probes to survey SSR sequences. The hybridization temperature was $64^{\circ} \mathrm{C}$ for each probe. Positive clones were isolated and sequenced, using an ABI 377 automatic sequencer, according to the manufacturer's instructions (Perkin-Elmer ABI Co. Ltd).

\section{Vectorette PCR}

This procedure was based on the protocol described by Lench et al. (1996). Genomic DNA of $S$. curtisii was digested with a mixture of restriction enzymes including Eco RI, Eco RV, Xba I and XhoI. Digested fragments between $500 \mathrm{bp}$ and $2500 \mathrm{bp}$ in size were fractionated. Fragments were then repaired by the Klenow method to make the ends blunt, and were ligated to pUC18. The ligation mixtures were transformed into E. coli JM109 and a DNA sample was prepared by alkaline lysis.

Vectorette PCR was performed in $25 \mu \mathrm{L}$ reaction volumes containing $10 \mathrm{ng}$ DNA from the genomic DNA library, and $0.128 \mathrm{M}$ universal or reverse vectorette primer for pUC18 (Primer 1: CCCAG TCACG ACGTT GT, or Primer 3: GGAAA CAGCT ATGAC CATG; Nippon Gene Co.) in combination with each one (separately) of the 12 anchored dinucleotide repeat primers: $(\mathrm{CT})_{10} \mathrm{~A}$, $(\mathrm{CT})_{10} \mathrm{~T},(\mathrm{CT})_{10} \mathrm{G},(\mathrm{CT})_{10} \mathrm{CA},(\mathrm{CT})_{10} \mathrm{CG},(\mathrm{CT})_{10} \mathrm{CC}$, $(\mathrm{CA})_{10} \mathrm{~A},(\mathrm{CA})_{10} \mathrm{~T},(\mathrm{CA})_{10} \mathrm{G},(\mathrm{CA})_{10} \mathrm{CT},(\mathrm{CA})_{10} \mathrm{CG}$ and $(\mathrm{CA})_{10} \mathrm{CC}$. Reaction mixtures were denatured at $94^{\circ} \mathrm{C}$ for $3 \mathrm{~min}$, followed by 34 cycles of amplification consisting of: $94^{\circ} \mathrm{C}$ for $30 \mathrm{~s}, 55^{\circ} \mathrm{C}$ for $30 \mathrm{~s}$ and $72^{\circ} \mathrm{C}$ for $30 \mathrm{~s}$. Amplified fragments were then fractionated in $2 \%$ agarose gel. When a single fragment was observed, the PCR products were purified by
Suprec-02 columns (TAKARA Co). When multiple fragments were observed, individual fragments were picked up from the gel by pipette tip. The tips were washed in PCR reaction mixture directly, and a single fragment was obtained through one more PCR cycle. The isolated fragments, including SSR flanking regions, were sequenced. Specific forward primers were designed for the flanking regions of each SSR based on the sequence data with the aid of the OLIGO program (version 4.0; National Bioscience). Using the forward primers in combination with primers for the other side of the vectorette primers, vectorette libraries were reamplified by PCR. Amplified fragments were sequenced, and reverse primers were also designed.

\section{SSR polymorphism of S. curtisii}

PCR was performed in $20 \mu \mathrm{L}$ reaction volumes containing $12.5 \mathrm{ng}$ genomic DNA. The PCR annealing temperature was $52-56^{\circ} \mathrm{C}$, as appropriate for each pair of primers. PCR amplification conditions were as follows: reaction mixtures contained $10 \mathrm{~mm}$ Tris- $\mathrm{HCl}, \mathrm{pH} 8.0,50 \mathrm{~mm} \mathrm{KCl}, 1.5 \mathrm{~mm} \mathrm{MgCl}_{2}$, $0.16 \mathrm{~mm}$ each dNTP, $0.128 \mu \mathrm{M}$ of each primer, $12.5 \mathrm{ng}$ of template DNA, and 0.5 units of Taq polymerase. A PCR amplification was carried out for 3 $\min$ at $94^{\circ} \mathrm{C}$, followed by 35 cycles of $45 \mathrm{~s}$ at $94^{\circ} \mathrm{C}$, $30 \mathrm{~s}$ at $52-56^{\circ} \mathrm{C}$ and $45 \mathrm{~s}$ at $72^{\circ} \mathrm{C}$, with a final $3 \mathrm{~min}$ incubation at $72^{\circ} \mathrm{C}$ with GeneAmp PCR System Model 9600 (Perkin-Elmer ABI Co. Ltd). We investigated 40 individuals from the Semangkok Forest Reserve population in Selangor, Malaysia, to estimate the genetic diversity of each SSR locus. Fragment analysis was carried out using an ABI 310 Genetic Analyzer (Perkin-Elmer ABI Co. Ltd) and each fragment size was determined by the GENESCAN program (Perkin-Elmer ABI Co. Ltd). We also calculated the number of alleles, the allele frequency and the heterozygosity in each locus. We also carried out sequence analysis of amplified fragments to confirm the SSR in these fragments.

\section{Application of SSR primers to other dipterocarp species}

PCR was carried out using the five primer pairs (Shc01, 04, 07, 09 and Shc11) that showed the highest levels of polymorphism in S. curtisii. PCR conditions were the same except that the annealing temperature was set at $50^{\circ} \mathrm{C}$ for three cycles for each locus. All amplified fragments of Shc07 and Shc11 were sequenced, and randomly selected fragments obtained using the other five SSR loci were 
sequenced to confirm the SSR sequences in the various species.

\section{Results}

\section{Screening of SSRs}

Colony hybridization with two kinds of probes resulted in four positive clones being isolated from 6000 genomic $S$. curtisii clones. Though three clones contained SSR sequences, the repeat length of one was too short, and another clone was not long enough to design a primer. Consequently, only one SSR primer pair, Shc01, was obtained.

By the vectorette PCR method, 24 fragments were amplified independently out of 104 clones, 20 of which could be isolated. Thus, 20 fragments were sequenced, and 17 specific forward primers were designed (three of the fragments had AT-rich sequences which prohibited forward primer design). Using the forward primers in combination with the other side of the vectorette primer in PCR, 15 amplified fragments were acquired and sequenced. Each fragment contained an SSR sequence, but four of them had insufficient repeat numbers for PCR amplification. Finally, therefore, eight SSR loci, Shc02, Shc03, Shc04, Shc07, Shc08, Shc09, Shc11 and $S h c 17$, which could be amplified by PCR, were identified.
A summary of the SSR markers is shown in Table 1. Shc02, Shc03, Shc04, Shc08 and Shc09 were simple CT repeats and the others were compound repeats of CT, CA, AT and CTCA tetranucleotide repeats.

\section{Analysis of polymorphism of the SSRs}

Genetic diversity of eight SSR loci among $40 \mathrm{~S}$. curtisii specimens in the Semangkok Forest Reserve population was investigated. The number of alleles per locus ranged from two to 20 and the average was 7.9 (Table 2). The expected heterozygosity ranged from 0.180 to 0.922 and the average was 0.639. Four SSRs, Shc01, Shc04, Shc07 and Shc09, were highly polymorphic $\left(H_{\mathrm{e}}>0.8\right)$, and another four SSRs (Shc02, Shc03, Shc11 and Shc17) detected two to four alleles. Shc08 gave weak amplification and was not used for the diversity study.

For simple repeat loci such as Shc04 and Shc09, allele polymorphism was found to depend mainly on differences in the number of CT repeats. However, in some cases, short compound repeats were found in the SSRs, especially at the Shc11 and Shc17 loci. The polymorphism at these loci was found to depend on insertions or deletions in the flanking region. Shc01 and $S h c 07$ were also compound repeats, and highly polymorphic. Their polymorphism depended not only on differences in the repeat

Table 1 SSR loci in Shorea curtisii, forward and reverse primer sequences, marker sizes based on sequence data, and optimum primer annealing temperatures

\begin{tabular}{|c|c|c|c|c|}
\hline Locus & Repeat & PCR primer $\left(5^{\prime}\right.$ to $\left.3^{\prime}\right)$ & $\begin{array}{l}\text { PCR product } \\
\text { length }\end{array}$ & $\begin{array}{l}\text { Annealing } \\
\text { temp. }\left({ }^{\circ} \mathrm{C}\right)\end{array}$ \\
\hline Shc 01 & $(\mathrm{CT})_{8}(\mathrm{CA})_{10} \mathrm{CT}(\mathrm{CA})_{4} \mathrm{CTCA}$ & $\begin{array}{l}\text { GCTAT TGGCA AGGAT GTTCA } \\
\text { CTTAT GAGAT CAATT TGACA G }\end{array}$ & 152 & 56 \\
\hline Shc 02 & $(\mathrm{CT})_{2} \mathrm{CA}(\mathrm{CT})_{5}$ & $\begin{array}{l}\text { CACGC TTTCC CAATC TG } \\
\text { TCAAGA GCAGA ATCCA G }\end{array}$ & 149 & 54 \\
\hline Shc 03 & $(\mathrm{CT})_{8}$ & $\begin{array}{l}\text { TTGAA GGGAA GGCTA TG } \\
\text { CTTCT CAACT ACCTT ACC }\end{array}$ & 124 & 54 \\
\hline Shc 04 & $(\mathrm{CT})_{16}$ & $\begin{array}{l}\text { ATGAG TAACA AGTGA TGAG } \\
\text { TATTG ACGTG GAATC TG }\end{array}$ & 95 & 52 \\
\hline Shc 07 & $(\mathrm{CT})_{8} \mathrm{CA}(\mathrm{CT})_{5} \mathrm{CACCC}(\mathrm{CTCA})_{3} \mathrm{CT}(\mathrm{CA})_{10}$ & $\begin{array}{l}\text { ATGTC CATGT TTGAG TG } \\
\text { CATGG ACATA AGTGG AG }\end{array}$ & 169 & 54 \\
\hline Shc 08 & $(\mathrm{CT})_{16}$ & $\begin{array}{l}\text { GAGTC TGTGG TTGAT ATG } \\
\text { TTCTA TGCAAG GGCTT TTAG }\end{array}$ & 247 & 52 \\
\hline Shc 09 & $(\mathrm{CT})_{12}$ & $\begin{array}{l}\text { TTTCT GTATC CGTGT GTTG } \\
\text { GCGATT AAGCG GACCT CAG }\end{array}$ & 197 & 54 \\
\hline Shc 11 & $(\mathrm{CT})_{4} \mathrm{TT}(\mathrm{CT})_{5}$ & $\begin{array}{l}\text { ATCTG TTCTT CTACA AGCC } \\
\text { TTAGA ACTTG AGTCA GATAC }\end{array}$ & 166 & 54 \\
\hline Shc 17 & $(\mathrm{CT})_{5} \mathrm{AT}(\mathrm{CT})_{4}$ & $\begin{array}{l}\text { CTAGAATCCG CCATT TCC } \\
\text { CACAA ATACG TCTCC ATATC }\end{array}$ & 78 & 56 \\
\hline
\end{tabular}


Table 2 SSR allele number, and the expected heterozygosy for eight loci in the Semangkok population of Shorea curtisii

\begin{tabular}{|c|c|c|c|}
\hline Locus & Core sequence* & $\begin{array}{l}\text { Number of } \\
\text { alleles }\end{array}$ & $\begin{array}{c}\text { Heterozygosity } \\
\left(H_{\mathrm{e}}\right)\end{array}$ \\
\hline Shc01 & $(\mathrm{CT})_{\mathrm{n}}(\mathrm{CA})_{\mathrm{m}} \mathrm{CT}(\mathrm{CA})_{1} \mathrm{CTCA}$ & 20 & 0.922 \\
\hline Shc02 & $(\mathrm{CT})_{2} \mathrm{CA}(\mathrm{CT})_{\mathrm{n}} \mathrm{GC}(\mathrm{AT})_{2}$ & 2 & 0.180 \\
\hline Shc03 & $(\mathrm{CT})_{\mathrm{n}}$ & 3 & 0.591 \\
\hline Shc04 & $(\mathrm{CT})_{\mathrm{n}}$ & 12 & 0.844 \\
\hline Shc07 & $(\mathrm{CT})_{\mathrm{n}} \mathrm{CA}(\mathrm{CT})_{\mathrm{m}} \mathrm{CACCC}(\mathrm{CTCA})_{\mathrm{l}} \mathrm{CT}(\mathrm{CA})_{\mathrm{k}}$ & 11 & 0.810 \\
\hline Shc09 & $(\mathrm{CT})_{\mathrm{n}}$ & 9 & 0.818 \\
\hline Shc 11 & $(\mathrm{CT})_{\mathrm{m}}(\mathrm{A} / \mathrm{T}) \mathrm{T}(\mathrm{CT})_{\mathrm{n}}$ & 4 & 0.640 \\
\hline \multirow[t]{2}{*}{ Shc 17} & $(\mathrm{CT})_{5} \mathrm{AT}(\mathrm{CT})_{\mathrm{n}}$ & 2 & 0.304 \\
\hline & Average & 7.9 & 0.639 \\
\hline
\end{tabular}

${ }^{*} \mathrm{n}, \mathrm{m}, \mathrm{l}$ and $\mathrm{k}$ show the repeated nucleotides.

number of each repeat unit, but also on the combination of different repeat units. Therefore, we observed many alleles per locus for Shc01 and Shc07.

\section{Conservation of SSR loci within Dipterocarpaceae}

The primers developed for analysing five of the SSR loci were used to assess conservation of the loci among 30 species from 10 genera of the Dipterocarpaceae. Within the genus Shorea, all five SSRs were well conserved (Table 3), but multiple amplification products were obtained from $S$. lepidota, $S$. macrophylla, S. ovalis and S. scaberrima DNA using Shc01 primers, from $S$. scaberrima DNA using $S h c 07$ primers, and from $S$. lepidota DNA using $S h c 09$ primers. For species in the genus Hopea, Shc01, 07 and 11 were strongly amplified by PCR. However, Shc04 and 09 were amplified weakly from the DNA of certain Hopea species: Shc04 from H. latifolia, $H$. nervosa, $H$. sangal and $H$. subalata DNA, and Shc09 from $H$. dyeri DNA. All loci in Neobalanocarpus heimii, Parashorea lucida and Dryobalanops aromatica were strongly amplified, except for Shc04 in Parashorea. Among the other seven species (Dipterocarpus baudii, D. kerrii, D. oblongifolius, Anisoptera oblonga, Vatica odorata, Cotylelobium malayanum and Upuna bornensis), the sequences of the flanking SSR regions were found to be more conserved than they were in Shorea and Hopea.

Shc07 and 11 were selected for sequence analysis of the 30 test species. Shc07 was chosen because the PCR amplification lengths for this marker differed on 3\% agarose gels: Hopea species, in particular, giving longer lengths than other genera. Based on the sequence data for $S h c 07$, the average amplifica- tion length is $200 \mathrm{bp}$ in Hopea, $130 \mathrm{bp}$ in Neobalanocarpus heimii, $168 \mathrm{bp}$ in Shorea and Parashorea lucida, and $143 \mathrm{bp}$ in the other seven species included in the tribe Dipterocarpeae. Shc11 was selected because this locus was well amplified in all species except for Upuna bornensis. We observed some base substitutions between species at this locus, but the locus was well conserved within the family.

\section{Discussion}

In this study, nine polymorphic SSR markers were developed using two different strategies. Comparing the two strategies, a vectorette PCR approach may generally be a more useful strategy than the commonly used method of colony hybridization because it allows more rapid surveys of numerous clones. However, as shown in Table 1, some SSR loci isolated by the vectorette PCR method included short or compound repeats. Hybridization screening of genomic libraries allows SSR loci which have short or compound repeats to be discarded before primers are designed, but for the vectorette primer method, it was necessary to design forward primers for all possible SSR loci to obtain SSR core sequences. This problem could be overcome by optimization of PCR conditions. In the colony hybridization method, we could detect only one SSR locus. One of the reasons might be that we used a relatively high stringency condition for the hybridization.

The CT/AG motif in Shorea curtisii is as abundant as it is in other plants (Lagercrantz et al., 1993; Wang et al., 1994). Simple CA repeats, known to be common in animals, were not isolated in this study.

The polymorphism of Shc04 and 09, which have simple repeats, depends mainly on differences in CT 
repeat number, but the polymorphism of alleles involving compound repeat SSR loci is much more complex (Table 2). Such complexity may lead to errors in designating genotypes. In other words, even if amplified fragments are the same in size, they may not always have the same sequences. The complex compound repeats like Shc01 and Shc07 were found to be highly polymorphic, but it may be better to develop SSR markers only for simple repeat loci to limit errors in genotype identification. However, SSRs containing complex compound and interrupted repeats can be used for estimates of mutation rates and analysis of homoplasy (Jarne \& Lagoda, 1996).

The frequency of dinucleotide repeats in the genome of several woody plants has been assessed, the estimates ranging from one repeat every 64 to $1105 \mathrm{~kb}$ (Condit \& Hubbell, 1991). In our study, two SSRs were found out of 6000 clones from a genomic DNA library in which the average insert size was $400 \mathrm{bp}$, and eight SSR loci were isoalted out of 104 clones from a genomic library with an average insert size of $1500 \mathrm{bp}$. Thus, according to these results, although the frequency of the dinucleotide repeats in the Shorea genome could not be determined exactly, they seem to occur approximately once every $1200 \mathrm{~kb}$. In S. curtisii, therefore, dinucleotide repeats are apparently more widely separted than in most other species.

The SSR primers developed for $S$. curtisii are also useful for analysing other dipterocarp species. Therefore they are potentially powerful tools for

Table 3 Application of SSR primers developed for Shorea curtissi to other Dipterocarpaceae species

\begin{tabular}{|c|c|c|c|c|c|}
\hline \multirow[b]{2}{*}{ Species } & \multicolumn{5}{|c|}{ Locus } \\
\hline & Shc01 & Shc04 & Shc07 & Shc09 & Shc 11 \\
\hline Anisoptera oblonga & $\mathrm{S}$ & W & $\mathrm{S}$ & $\mathrm{S}$ & $\mathrm{S}$ \\
\hline Cotylelobium malayanum & $\mathrm{S}$ & $\mathrm{W}$ & $\mathrm{W}$ & W & $\mathrm{S}$ \\
\hline Dipterocarpus baudii & $\mathrm{S}$ & W & $\mathrm{S}$ & W & $\mathrm{S}$ \\
\hline Dipterocarpus kerrii & $\mathrm{S}$ & W & $\mathrm{M}$ & W & $\mathrm{S}$ \\
\hline Dipterocarpus oblongifolius & $\mathrm{S}$ & W & $\mathrm{S}$ & $\mathrm{S}$ & $\mathrm{S}$ \\
\hline Dryobalanops aromatica & $\mathrm{S}$ & $\mathrm{S}$ & $\mathrm{S}$ & $\mathrm{S}$ & $\mathrm{S}$ \\
\hline Hopea apiculata & $\mathrm{S}$ & $\mathrm{S}$ & W & $\mathrm{S}$ & $\mathrm{S}$ \\
\hline Hopea dyeri & $\mathrm{S}$ & $\mathrm{S}$ & $\mathrm{S}$ & $\mathrm{W}$ & $\mathrm{S}$ \\
\hline Hopea helferi & $\mathrm{S}$ & W & $\mathrm{S}$ & $\mathrm{W}$ & $\mathrm{S}$ \\
\hline Hopea latifolia & $\mathrm{M}$ & W & $\mathrm{S}$ & $\mathrm{S}$ & $\mathrm{S}$ \\
\hline Hopea nervosa & $\mathrm{S}$ & $\mathrm{W}$ & $\mathrm{S}$ & - & $\mathrm{S}$ \\
\hline Hopea odorata & $\mathrm{S}$ & $\mathrm{S}$ & $\mathrm{S}$ & $\mathrm{S}$ & $\mathrm{S}$ \\
\hline Hopea sangal & $\mathrm{S}$ & $\mathrm{W}$ & $\mathrm{S}$ & $\mathrm{S}$ & $\mathrm{S}$ \\
\hline Hopea subalata & $\mathrm{S}$ & W & $\mathrm{S}$ & $\mathrm{S}$ & $\mathrm{S}$ \\
\hline Hopea wightiana & $\mathrm{S}$ & $\mathrm{S}$ & $\mathrm{S}$ & $\mathrm{S}$ & $\mathrm{S}$ \\
\hline Neobalanocarpus heimii & $\mathrm{S}$ & $\mathrm{S}$ & $\mathrm{S}$ & $\mathrm{S}$ & $\mathrm{S}$ \\
\hline Shorea atrinervosa & $\mathrm{S}$ & $\mathrm{S}$ & $\mathrm{S}$ & $\mathrm{S}$ & $\mathrm{S}$ \\
\hline Shorea bracteolata & $\mathrm{S}$ & $\mathrm{S}$ & $\mathrm{S}$ & $\mathrm{S}$ & $\mathrm{S}$ \\
\hline Shorea kunstleri & $\mathrm{S}$ & $\mathrm{S}$ & $\mathrm{S}$ & $\mathrm{S}$ & $\mathrm{S}$ \\
\hline Shorea lepidota & M & $\mathrm{S}$ & $\mathrm{S}$ & $\mathrm{M}$ & $\mathrm{S}$ \\
\hline Shorea macrophylla & $\mathrm{M}$ & $\mathrm{S}$ & $\mathrm{S}$ & $\mathrm{S}$ & $\mathrm{S}$ \\
\hline Shorea macroptera & $\mathrm{S}$ & $\mathrm{S}$ & $\mathrm{S}$ & $\mathrm{S}$ & $\mathrm{S}$ \\
\hline Shorea multiflora & $\mathrm{S}$ & $\mathrm{S}$ & $\mathrm{S}$ & $\mathrm{S}$ & $\mathrm{S}$ \\
\hline Shorea ovalis & M & $\mathrm{S}$ & $\mathrm{S}$ & $\mathrm{S}$ & $\mathrm{S}$ \\
\hline Shorea parvifolia & $\mathrm{S}$ & $\mathrm{S}$ & $\mathrm{S}$ & $\mathrm{S}$ & $\mathrm{S}$ \\
\hline Shorea scaberrima & $\mathrm{M}$ & $\mathrm{S}$ & $\mathrm{M}$ & $\mathrm{S}$ & $\mathrm{S}$ \\
\hline Shorea singkawang & $\mathrm{S}$ & $\mathrm{S}$ & $\mathrm{S}$ & $\mathrm{S}$ & $\mathrm{S}$ \\
\hline Parashorea lucida & $\mathrm{S}$ & - & $\mathrm{S}$ & $\mathrm{S}$ & $\mathrm{S}$ \\
\hline Vatica odorata & $\mathrm{S}$ & W & $\mathrm{S}$ & $\mathrm{S}$ & $\mathrm{S}$ \\
\hline Upuna bornensis & $\mathrm{M}$ & - & $\mathrm{S}$ & $\mathrm{S}$ & W \\
\hline
\end{tabular}

S, strong amplification; $\mathrm{W}$, weak amplification; - , amplification failed; $\mathrm{M}$, multiple bands amplified. 
genetic analysis of the tropical forest. The results also indicate that affinities among these species are relatively close. Methods of phylogenetic inference using SSRs have recently been discussed by Goldstein \& Pollock (1997) and Ellegren et al. (1997).

Recently, molecular phylogenies of the same 30 species of Dipterocarpaceae were constructed using PCR-RFLP analysis of chloroplast genes (Tsumara et al., 1996) and sequence analysis of chloroplast DNA (Kajita et al., 1998). According to these studies, there are two major groups of Dipterocarpaceae: Shoreae, which includes Shorea, Hopea, Parashorea, Neobalanocarpus and Dryobalanops, and Dipterocarpeae, which includes Dipterocarpus, Anisoptera, Upuna and Cotylelobium. The molecular phylogeny analysis also revealed close affinities among Shorea, Hopea, Parashorea, Neobalanocarpus and Dryobalanops.

PCR amplification patterns of these 30 species, using the five SSR loci markers developed for Shorea curtisii, do not show clear correlations with the molecular phylogeny. However, the amplification patterns of Shc04 and Shc09 suggest that the sequences of the flanking regions of these SSR loci are not well conserved in relatively distant species. These loci were well amplified in Shorea, but not in several species from other genera. Dayanandan et al. (1997) showed that SSR loci developed for Pithecellobium elegans were conserved among closely related species, and that there is high potential for the transfer of SSR markers between closed related taxa, as in our study. Conservation of SSRs for closely related plant taxa was also reported by Kijas et al. (1995) and Wu \& Tanksley (1993). Some reports in animals have also shown similar observations (Moore et al., 1991; Schlotterer et al., 1991; Levine et al., 1995) but sequences were not conserved in humans (Moore et al., 1991)

The average size of $S h c 07$ amplification length also seems to correlate well with the molecular phylogeny. According to the sequence data, these differences mainly depend on CATA repeats in core sequences. In the tribe Dipterocarpeae, CATA repeats do not seem to exist. In contrast, although base substitutions in $S h c 11$ were detected in several species, it is not clear whether this reflects genetic distance.

In tropical tree species, several studies have reported the development and use of SSR markers (Terauchi, 1994; Chase et al., 1996a,b; White \& Powell, 1997). However, further study is required in order to evaluate the generality of SSR conservation, and to understand the evolution of SSR markers during speciation, and the genetic mechanisms involved.

\section{Acknow ledgements}

The authors thank K. Niiyama, H. Tanouchi, T. Katsuki, K. Yoshimura and the staff of FRIM for helping to collect Shorea curtisii samples. This study was supported by grant no. E-1 under the Global Environment Research Programme of the Japan Environment Agency.

\section{References}

CHARLESWORTH, B., SNIEGOWASKI, P. AND STEPHAN, W. 1994. The evolutionary dynamics of repetitive DNA in eukaryotes. Nature, 371, 215-220.

CHASE, M., KESSELI, M. R. AND BAWA, K. s. 1996a. Microsatellite markers for population and conservation genetics of tropical trees. Am. J. Bot., 83, 51-57.

CHASE, M., KeSSEli, M. R. AND BAWA, K. S. 1996b. Distant gene flow in tropical trees. Nature, 383, 398-399.

Cifarelli, R. A., Gallitelli, M. AND CELlini, F. 1995. Random amplified hybridization microsatellites (RAHM): isolation of a new class of microsatellitecontaining DNA clones. Nucl. Acids Res., 23, 3802-3803.

CONDIT, R. AND HUBBELL, s. P. 1991. Abundance and DNA sequence of two-base repeat regions in tropical tree genomes. Genome, 34, 66-71.

DAYANANDAN, S., BAWA, K. S. AND KESSELI, R. 1997. Conservation of microsatellites among tropical trees (Leguminosae). Am. J. Bot., 84, 1658-1663.

DOW, B. D., AShley, M. V. AND HOWE, H. F. 1995. Characterization of highly variable $(\mathrm{GA} / \mathrm{CT}) \mathrm{n}$ microsatellites in the bur oak, Quercus macrocarpa. Theor. Appl. Genet., 91, 137-141.

ECHT, C. S., MAY-MARquARDT, P., HSEIH, M. AND ZAHORCHAK, R. 1996. Characterization of microsatellite markers in eastern white pine. Genome, 39, 1102-1108.

ELLEGREN, H., MOORE, S., ROBINSON, N., BYRNE, K., WARD, w. AND SHELDON, B. C. 1997. Microsatellite evolution a reciprocal study of repeat length at homologous loci in cattle and sheep. Mol. Biol. Evol., 14, 854-860.

GOLDSTEIN, D. B. AND POLLOCK, D. D. 1997. Launching microsatellites: A review of mutation processes and methods of phylogenetic inference. J. Hered., 88, 335-342.

JARNE, P. AND LAGODA, P. J. L. 1996. Microsatellies, from molecules to populations and back. Trends Ecol. Evol., 11, 424-429.

KAJITA, T., KAMIYA, K., NAKAMURA, K., WICKNESWARI, R., YOSHIMARU, H., TSUMURA, Y. ET AL. 1998. Molecular phylogeny of Dipterocarpaceae in Southeast Asia based on nucleotide sequence of $m a t \mathrm{~K}, \operatorname{trn} \mathrm{L}$ intron and $\operatorname{trn} \mathrm{L}-$ $\operatorname{trn} \mathrm{F}$ intergenic spacer region in chloroplast DNA. Mol. Phyl. Evol., (in press). 
KARAGYOZOV, L., KALChEVA, I. D. AND CHAPMAN, V. M. 1993. Construction of random small-insert genomic libraries highly enriched for simple sequence repeats. Nucl. Acids Res., 21, 3911-3912.

KIJAS, J. M. H., FOWLER, J. C. S. AND THOMAS, M. R. 1995. An evaluation of sequence tagged microsatellite site markers for genetic analysis within Citrus and related species. Genome, 38, 349-355.

KIRKPATRICK, B. W., BRADSHAW, M., BARENDSE, W. AND DENTINE, M. R. 1995. Development of bovine microsatellite markers from a microsatellite-enriched library. Mammalian Genome, 6, 526-528.

KOSTIA, S., VARVIO, S. L., VAKKARI, P. AND PULKKINEN, P. 1995. Microsatellite sequences in a conifer, Pinus sylvestris. Genome, 38, 1244-1248.

LAGERCRANTZ, U., ELLEGREN, H. AND ANDERSSON, L. 1993. The abundance of various polymorphic microsatellite motifs differs between plants and vertebrates. Nucl. Acids Res., 21, 1111-1115.

LENCH, N. J., NORRIS, A., BAILEY, A., BOOTH, A. AND MARKHAM, A. F. 1996. Vectorette PCR isolation of microsatellite repeat sequences using anchored dinucleotide repeat primers. Nucl. Acids Res., 24, 2190-2191.

LEVINE, I., CHENG, H. H., BACTER, J. C. AND HILLEL, J. 1995. Turkey microsatellite DNA loci amplified by chicken specific primers. Anim. Genet., 26, 107-110.

LYALL, J. E. W., BROWN, G. M., FURLONG, R. A., FERGUSONSMITH, M. A. AND AFFARA, N. A. 1993. A method for creating chromosome-specific plasmid libraries enriched in clones containing $[\mathrm{CA}]_{\mathrm{n}}$ microsatellite repeat sequences directly from flow-sorted chromosomes. Nucl. Acids Res., 21, 4641-4642.

MOORE, S. S., SARGEANT, L. L., KING, T. J., MATICK, J. S., GEORGES, M. AND HETZEL, D. J. 1991. The conservation of dinucleotide microsatellites among mammalian genomes allows the use of heterologous PCR primer pairs in closely related species. Genome, 10, 654-660.
NIIYAMA, K., RAHMAN, K., IIDA, S., KIMURA, K. AND APPANAH, s. 1993. Introduction of ecological studies in a hill dipterocarp forest in Peninsula Malaysia. Jap. J. For. Envir., 35, 25-29.

OSTRANDER, E. A., JONG, P. M., RINE, J. AND DUYK, G. 1992. Construction of small-insert genomic DNA libraries highly enriched for microsatellite repeat sequences. Proc. Natl. Acad. Sci. U.S.A., 89, 3419-3423.

SCHLOtTerer, C., AMOS, B. AND TAUTZ, D. 1991. Conservation of polymorphic simple sequence loci in cetecean species. Nature, 354, 63-65.

SMITH, D. N. AND DEVEY, M. E. 1994. Occurrence and inheritance of microsatellites in Pinus radiata. Genome, 37, 977-983.

TAKAHASHI, H., NIRAWASA, K. AND FURUKAWA, T. 1996. An efficient method to clone chicken microsatellite repeat sequence. Jap. Poultry Sci., 33, 292-299.

TERAUCHI, R. 1994. A polymorphic microsatellite marker from the tropical tree Dryobalanops lanceolata (Dipterocarpaceae). Jpn. J. Genet., 69, 567-576.

TSUMURA, Y., KAWAHARA, T., WIEKNESWARI, R. AND YOSHIMURA, K. 1996. Molecular phylogeny of Dipterocarpaceae in Southeast Asia using RFLP of PCR-amplified chloroplast genes. Theor. Appl. Genet., 93, 22-29.

VAN DE VEN, W. T. G. AND McNICOL, R. J. 1996. Microsatellites as DNA markers in Sitka spruce. Theor. Appl. Genet., 93, 613-617.

WANG, Z., WEBER, J. L., ZHONG, G. AND TANKSLEY, S. D. 1994. Survey of plant short tandem DNA repeats. Theor. Appl. Genet., 88, 1-6.

WHITE, G. AND POWELL, w. 1997. Isolation and characterization of microsatellite loci in Swietenia humilis (Meliaceae): an endangered tropical hardwood species. Mol. Ecol., 6, 851-860.

WU, K. AND TANKSLEY, S. D. 1993. Abundance, polymorphism and genetic mapping of microsatellites in rice. Mol. Gen. Genet., 241, 225-235. 